\title{
Adult Neurogenesis Produces Neurons with Unique GABAergic Synapses in the Olfactory Bulb
}

\author{
Matthew T. Valley, ${ }^{1,3}$ Lansdale G. Henderson, ${ }^{1,3}$ Samuel A. Inverso, ${ }^{2,3}$ and Pierre-Marie Lledo ${ }^{1,3}$ \\ ${ }^{1}$ Laboratory for Perception and Memory and ${ }^{2}$ Integrative Neurobiology of Cholinergic Systems, Pasteur Institute, F-75015 Paris, France, and ${ }^{3}$ National \\ Center of Scientific Research, Coeducational Research Unit, Centre National de la Recherche Scientifique, Unité Mixte de Recherche 3571, F-75015 Paris, \\ France
}

Neuronal regeneration occurs naturally in a few restricted mammalian brain regions, but its functional significance remains debated. Here we search for unique features in the synaptic outputs made by adult-born granule cell interneurons in the mouse olfactory bulb using optogenetic targeting of specific neuronal ages. We find that adult-born interneurons are resistant to presynaptic $\mathrm{GABA}_{\mathrm{B}}-\mathrm{mediated}$ depression of GABA release compared with interneurons born just after birth that exhibit strong $\mathrm{GABA}_{\mathrm{B}}$ neuromodulation. Correlated with this functional change, we found altered localization of the $\mathrm{GABA}_{\mathrm{B}} \mathrm{R} 1$ protein within adult-born granule cells. These results suggest that adult neurogenesis produces a population of functionally unique GABAergic synapses in the olfactory bulb.

\section{Introduction}

Interneurons are continuously regenerated in the adult mammalian olfactory bulb $(\mathrm{OB})$ in which they create new synapses (Carleton et al., 2003) and participate in olfactory learning and memory (Alonso et al., 2012). The vast majority of adultgenerated interneurons become granule cells (GCs), and these small neurons pack the core of the OB in which they can survive for the life of the animal. Continuous arrival and replacement of GCs makes the OB (and dentate gyrus) unique within the brain by possessing a dynamically changing composition of neurons born from embryogenesis through adulthood. Within this mélange, it is important to know how cell birth date and cell maturity influences the function of each GC in the circuit.

There are several physiological differences between immature GCs and those that have matured and are stably integrated within the circuit. The function of all GCs relates to how they focus efferent, collateral, and centrifugal inputs into a single inhibitory output. Before forming output synapses, the maturation and survival of immature GCs appears to be uniquely sensitive to these diverse inputs. Previous work has shown that the formation of synaptic inputs onto GCs occurs soon after they arrive in the OB and is activity dependent (Whitman and Greer, 2007; Kelsch et al., 2009), transiently exhibits increased long-term plasticity (Gao

\footnotetext{
Received July 4, 2013; revised Aug. 1, 2013; accepted Aug. 5, 2013.

Author contributions: M.T.V. and P.-M.L. designed research;M.T.V. performed research; M.T.V., L.G.H., and S.A.I. analyzed data; M.T.V. and P.-M.L. wrote the paper.

This work was supported by the life insurance company Arpège Prévoyance, National Agency for Research Grant ANR-BLAN-SVSE4-LS-110624 , "ANR-09-NEUR-004" in the frame of "ERA-NET NEURON" of FP7 program by the European Commission, and a Pasteur-Roux postdoctoral fellowship (M.T.V.). We thank Karl Deisseroth for ChR2 plasmid vectors and Bernhard Bettler and Martin Gassmann for GABA-B KO mice lines. We thank members of the Lledo laboratory for their helpful comments on this manuscript.

Correspondence should be addressed to Pierre-Marie Lledo, Laboratory for Perception and Memory, Pasteur Institute and National Center of Scientific Research, 25 rue du Dr. Roux, F-75724 Paris Cedex 15, France. E-mail: pmlledo@pasteur.fr.

S. A. Inverso's present address: Wyss Institute, Harvard University, Boston, MA 02115

DOI:10.1523/JNEUROSCI.2845-13.2013

Copyright $\odot 2013$ the authors $\quad 0270-6474 / 13 / 3314660-06 \$ 15.00 / 0$
}

and Strowbridge, 2009; Nissant et al., 2009), and can instruct the survival or death of the young neuron (Lin et al., 2010; Yokoyama et al., 2011). This indicates that, compared with mature GCs, immature GCs may have a specific function within the circuit related to their input connectivity.

In contrast, little is known about the functional differences between GCs born at different periods in the animal's life. In a recent study, a difference was found between mature GCs born just after birth (referred to here as "postnatal-born" cells) and mature adult-born GCs in their ability to augment the rate of olfactory learning (Alonso et al., 2012). This provided the first evidence that mature GCs born at different times might hold different circuit functions and drove us to search for unique features in the output of mature adult-born GCs in vitro.

We searched for differences in synaptic transmission from mature GCs as a function of their birth date and found that presynaptic $\mathrm{GABA}_{\mathrm{B}}$ regulation of GABA release was absent in adult-born GCs but not in GCs born in early postnatal neurogenesis. Surprisingly, adult-born GCs showed redistributed $\mathrm{GABA}_{\mathrm{B}}$ receptor $\left(G_{A B A} R\right)$ immunoreactivity localized toward the dendrite core, indicating that their resistance to neuromodulation may relate to altered localization of the $G_{A B A} R$ protein.

\section{Materials and Methods}

Animals. C57BL/6J mice (Centre d'Elevage Janvier) were delivered as adults of either sex (7-8 weeks old) or as pups with mother (P6 pups). All procedures were in line with the European Communities Council Directive of November 24, 1986 (86/609/EEC) and the European Union guidelines and were reviewed and approved by the Animal Welfare Committee of the Pasteur Institute.

Viral injections. A replication-deficient lentiviral vector expressed a channelrhodopsin-2 (ChR2)-enhanced yellow fluorescent protein (YFP) fusion construct under control of the synapsin 1 [hChR2(H134R)YFP]. The concentration of lentiviral vector particles was $14.2 \mathrm{ng} \mathrm{P} 24 / \mu \mathrm{l}$ as assayed by ELISA (PerkinElmer Life and Analytical Sciences), and average vector titers were in the order of $10^{10}$ transduction units $/ \mathrm{ml}$. Only a small fraction of ChR2-expressing $\left(\mathrm{ChR} 2{ }^{+}\right)$cells expressed dou- 
a
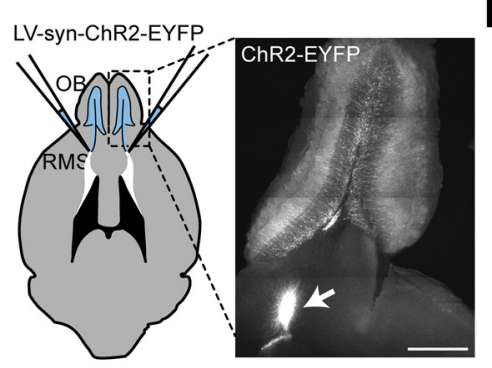

d

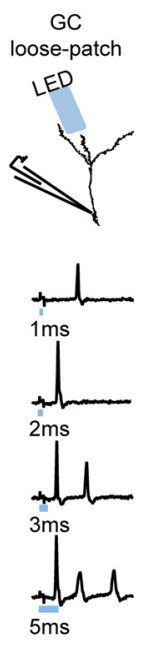

$\mathbf{e}$

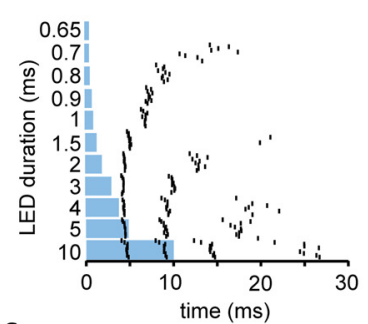

f

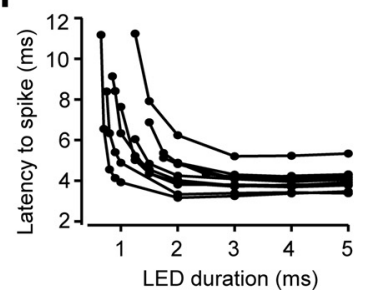

b

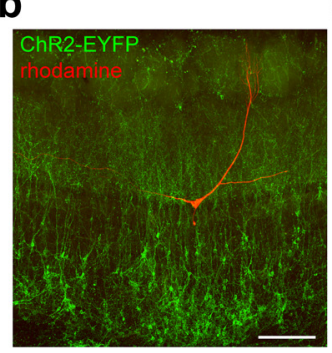

g

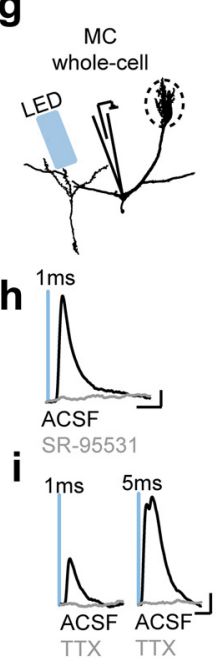

c

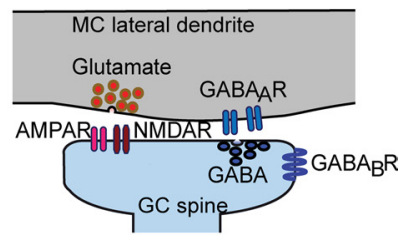

j

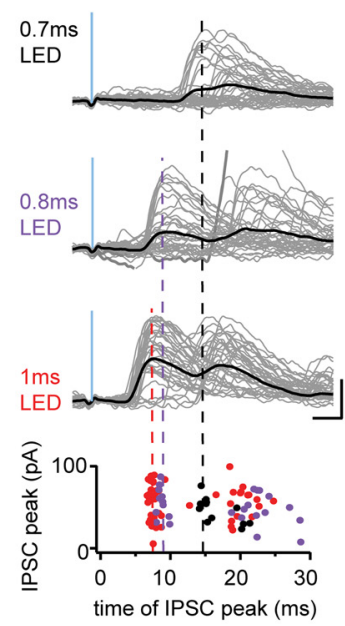

Figure 1. ChR2 evokes synchronous GABA release from adult-born GCS. $\boldsymbol{a}, \mathrm{A} C \mathrm{ChR2}$ lentivirus injected into the RMS infects immature $\mathrm{GC}$ neuroblasts migrating toward the $0 \mathrm{~B}$. Right inset, Horizontal slice of the OB 4 weeks after injection showing the injection site (arrow) distal to the OB. Scale bar, $1 \mathrm{~mm}$. $\boldsymbol{b}$, Confocal stack of reconstructed MC (red) and ChR2 ${ }^{+} \mathrm{GCs}$ (green). Scale bar, $100 \mu \mathrm{m}$. $\boldsymbol{c}$, Schematic of the dendrodendritic synapse between MCs and GCs showing the putative location of $G_{A B A} A_{B} R s$. $\boldsymbol{d}, \boldsymbol{e}$, Example traces $(\boldsymbol{d})$ and example raster plot $(\boldsymbol{e})$ of spikes recorded in a loose-patch configuration at different stimulation durations using an LED (10 trials per duration, left). $\boldsymbol{f}$, Relationship between the latency to first spike and the LED duration (mean threshold to spike, $1.5 \pm 0.2$ $\mathrm{ms}$; mean minimum latency to spike, $4.1 \pm 0.3 \mathrm{~ms} ; n=9$ cells). $\boldsymbol{g}$, Schematic of setup to measure postsynaptic currents in an MC. $\boldsymbol{h}, \boldsymbol{i}$, Average MC IPSCs from 8 weeks after injection for ChR2 ${ }^{+} \mathrm{GCS}$ (injected at P60) before (black) and after (gray) administration of $\mathrm{GABA}_{\mathrm{A}}$ antagonist SR-95531 [6-Imino-3-(4-methoxyphenyl)-1(6H)-pyridazinebutanoic acid hydrobromide] (10 $\mu$ m; calibration: $10 \mathrm{pA}, 10 \mathrm{~ms})(\boldsymbol{h})$ and Na-channel antagonist TTX $(1 \mu \mathrm{m})$ at short $(1 \mathrm{~ms})$ and long $(5 \mathrm{~ms})$ stimulation durations (calibration: $10 \mathrm{pA}, 20 \mathrm{~ms})$ (i).j. Example individual IPSCs (gray lines) and average IPSCs (black line) recorded from an MC at different LED stimulation durations (top; calibration: $40 \mathrm{pA}, 5 \mathrm{~ms}$ ). With increasing LED duration, the aligned peak times of each IPSC (bottom) exhibited latency precession similar to what we observed with GC spikes.

blecortin (3\% at 12 weeks after injection), confirming that viral injections produce a birth-dating event that is restricted in time (Bardy et al., 2010; Alonso et al., 2012). For P60 stereotaxic injections, animals were anesthetized intraperitoneally [3.0 $\mathrm{mg}$ of ketamine (Imalgene); $0.25 \mathrm{mg}$ of xylazine (Rompun; Bayer)]. Bilateral craniotomies were drilled above the rostral migratory stream (RMS) at the following stereotaxic coordinates from bregma: anteroposterior (AP), $+3.3 \mathrm{~mm}$; mediolateral (ML), $\pm 0.82 \mathrm{~mm}$; dorsoventral (DV), $-2.90 \mathrm{~mm}$ from the pial surface. Viral vector particles $(200 \mathrm{nl} / \mathrm{site})$ were injected (Nanoject II; Drummond) with a glass micropipette at a rate of $23 \mathrm{nl} / \mathrm{s}$. For P6 injections, mouse pups were deeply anesthetized on ice for $7 \mathrm{~min}$ and positioned in a homemade cast. Bilateral RMS injections were made relative to the bisection of the superior sagittal sinus and the rostral rhinal vein at the following coordinates: AP, $-0.6 \mathrm{~mm}$; $\mathrm{ML}, \pm 0.6 \mathrm{~mm}$; DV,$-2.1 \mathrm{~mm}$. After resuscitation under dry heat (10-30 $\mathrm{min})$ pups were returned to their mother. After weaning (at P21), mice were segregated by gender.

Electrophysiology. Tissue was dissected in ACSF (in mM: $124 \mathrm{NaCl}, 3$ $\mathrm{KCl}, 1.3 \mathrm{MgSO}_{4}, 26 \mathrm{NaHCO}_{3}, 1.25 \mathrm{NaH}_{2} \mathrm{PO}_{4}, 20$ glutamate, and $2 \mathrm{CaCl}_{2}$; Sigma). Three-hundred-micrometer-thick sections were vibrosectioned (VT1200S; Leica) and kept in the dark. Slices were accepted based on the location of the injection site (see Fig. 1a) and by the absence of YFP ${ }^{+}$ projection neurons and axons. Recordings were made under ACSF perfusion $(1-2 \mathrm{ml} / \mathrm{min})$ held at $25-26^{\circ} \mathrm{C}$. Borosilicate glass pipettes $(1.12$ $\mathrm{mm}$ inner diameter, $1.5 \mathrm{~mm}$ outer diameter) were pulled (P-97; Sutter Instruments) to a tip resistance between 3 and $6 \mathrm{M} \Omega$. Voltage-clamp internal solutions contained $116 \mathrm{~mm}$ Cs-gluconate, $6 \mathrm{~mm} \mathrm{CsCl,} 2 \mathrm{~mm}$ $\mathrm{NaCl}, 10$ mм Na-HEPES, 10 mm Cs-EGTA, 0.3 mm GTP, 0.2 mм cAMP,
2 mm Mg-ATP, pH 7.3, 290-300 mOsm, with 0.15\% biocytin and $0.06 \%$ rhodamine. For all experiments except for Figure $2 f$, the extracellular ACSF was the same as the slicing solution. For the experiment in Figure $2 f$, extracellular calcium was balanced with magnesium for a total divalent cation concentration of $7 \mathrm{~mm}$. Mitral cells (MCs) were identified under infrared differential interference contrast optics ( $40 \times, 0.8$ numerical aperture; Olympus) by the position and shape of the soma within the MClayer. All MCs exhibited spontaneous spiking on-cell, and their input resistance varied between 50 and $120 \mathrm{M} \Omega$ in whole cell. Pipette capacitances were compensated on-cell $(\sim 10-15 \mathrm{pF})$. Recordings were discarded if the access resistance exceeded half of the input resistance of the cell or if the access resistance varied by $>30 \%$ during the experiment. Data were digitized at $10 \mathrm{kHz}$ (EPC9 double; HEKA). To record IPSCs from MCs, we held the membrane at a depolarized potential $(+10 \mathrm{mV})$ in the presence of bath-applied kyurenic acid (5 mM; Sigma) or NBQX (10 $\mu$ m; Sigma) with APV (20 $\mu \mathrm{M}$; Sigma). $R / S$-Baclofen (Tocris Biosciences) was kept in frozen stocks diluted in $10 \mathrm{~mm} \mathrm{NaOH}$ at a concentration of 25 mM. CGP 55845 [(2S)-3-[(15)-1-(3,4-dichlorophenyl)ethyl] amino-2-hydroxypropyl)(phenylmethyl)phosphinic acid] (Tocris Bioscience) was dissolved in DMSO at $10 \mathrm{~mm}$. Control ACSF contained the amount of solvent added with baclofen and CGP 55845. Electrical stimuli were in the external plexiform layer for $200 \mu$ s at $20-100 \mu \mathrm{A}$. ChR2 stimulation used a $470 \mathrm{~nm}$ light-emitting diode (LED) array (Bridgelux) that projected through the condenser of the microscope. Peak light intensity at the focus of the condenser was $6.88 \mathrm{~mW} / \mathrm{mm}^{2}$, which declined radially at $\sim 20 \% / \mathrm{mm}$. Light duration was controlled using a digital sequencer (Master-8; A.M.P.I ), and all stimulations were given with an interstimulus interval 
a

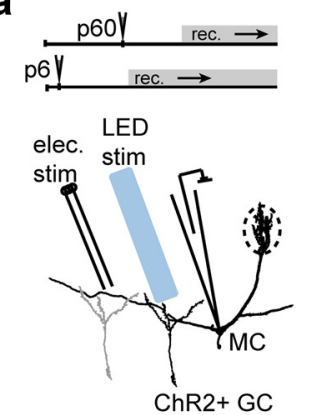

b

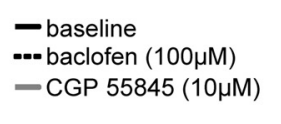

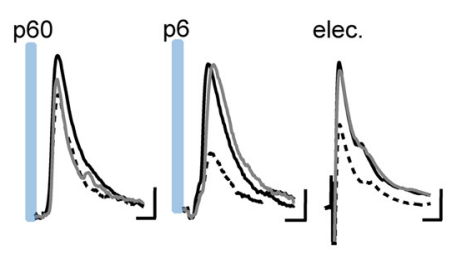
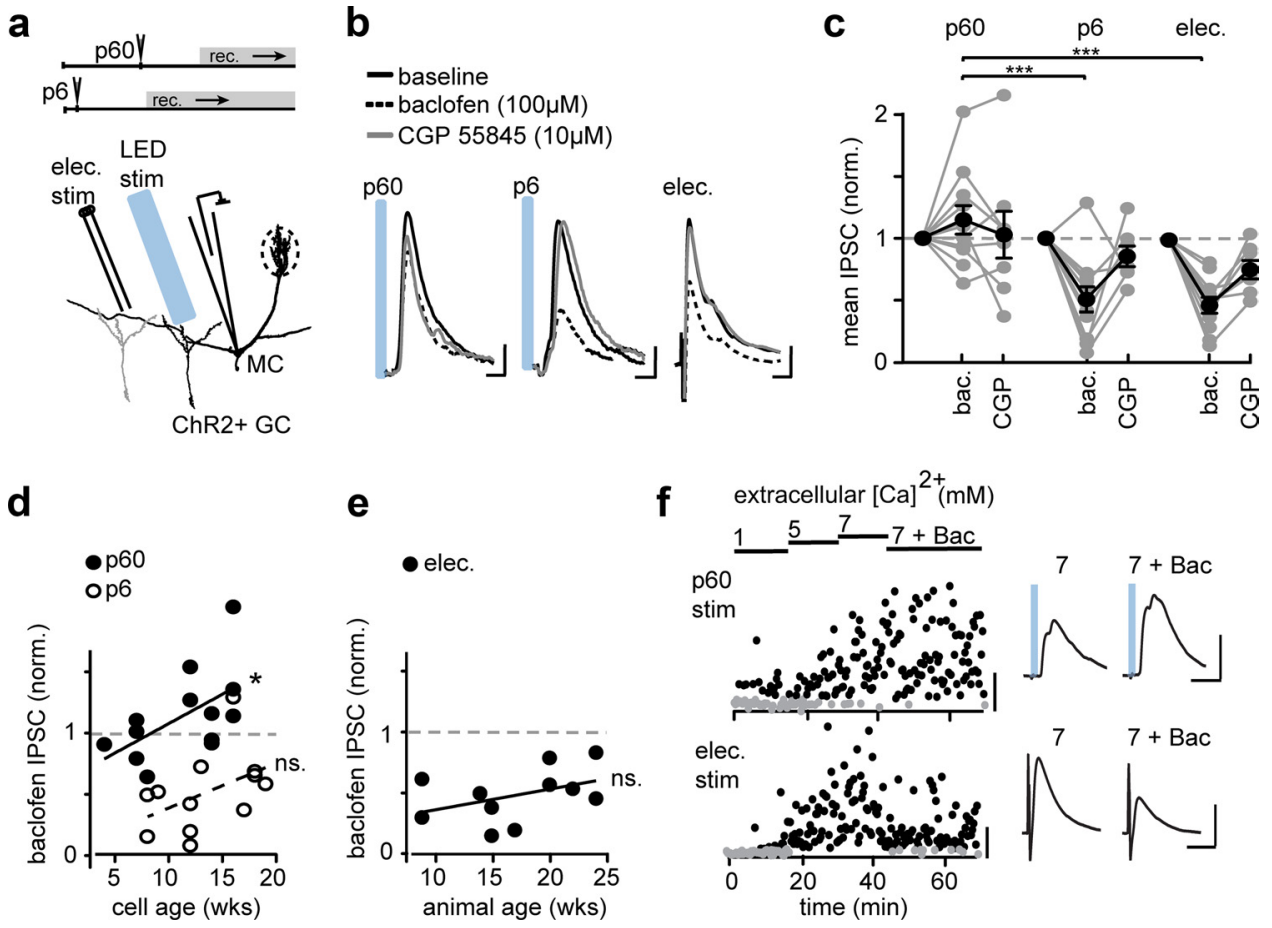

Figure 2. GABA release from adult-born $\mathrm{GCS}$ resists $\mathrm{GABA}_{\mathrm{B}} \mathrm{R}$ modulation. $\boldsymbol{a}$, Schematic of differential screen showing the time of (hR2 injection (top) and the simultaneous recording of electrically and optically evoked IPSCs. $\boldsymbol{b}$, Example averaged traces of IPSCs from three different GC populations. Calibration: P6, P60, 10 ms, 10 pA; electrically evoked, 10 ms, 100 pA. c, Change in IPSC magnitude in response to $\mathrm{GABA}_{\mathrm{B}} \mathrm{R}$ agonist baclofen (bac.) and antagonist CGP 55845 (CGP) normalized to baseline. ${ }^{*} p<0.0001$, Newman-Keuls test, ANOVA. $\boldsymbol{d}$, Same data as $\boldsymbol{C}$ with linear regression between the effect of baclofen and neuron age for neurons born at P6 (open circles) and P60 (filled circles). ${ }^{*} p<0.05$, least-squares regression. $e$, Linear regression between the effect of baclofen on electrical responses and the age of the animal at the time of recording. $f$, P60 ChR2 stimulation under conditions of increased release probability using a ramp of extracellular [ $\mathrm{Ca}^{2+}$ ] from 1 to $7 \mathrm{~mm}$ and in the presence of baclofen (Bac, $100 \mu \mathrm{m}$ ). IPSCs are counted above a threshold ( $20 \mathrm{pA}$, black circles), and events below this threshold are considered failures (gray circles). Calibration: p60, 50 pA; electrically evoked, 100 pA. Average traces during $7 \mathrm{~mm} \mathrm{Ca}{ }^{2+}$ and Ca ${ }^{2+}$ plus baclofen shown in inset (right) for P60 ChR2-evoked IPSCs (top) and electrically evoked IPSCs (bottom). Calibration: p60 and electrically evoked, 25 ms, 100 pA.

of $20 \mathrm{~s}$. IPSCs were included for analysis on the basis of the time of their onset (for raw traces, see Fig. 1j), excluding IPSCs after the first. ChR2 sometimes evoked multiple IPSC peaks even at low stimulation durations, indicating either spike bursts or multiple independent release sites responding with different latencies. This precluded analysis of shortterm plasticity because it was not possible to know which IPSC represented release to the second presynaptic spike.

Immunohistochemistry. Tissue was dissected as a whole brain in the same manner as for slice electrophysiology and immersion fixed in $4 \%$ paraformaldehyde on ice for $45 \mathrm{~min}$. Fifty-micrometer-thick floating sections were vibrosliced, blocked with $5 \%$ goat and bovine serum plus $20 \mathrm{~mm}$ glycine in $0.1 \%$ Triton $\mathrm{X}-100$, and incubated in primary antibody for $72 \mathrm{~h}$. Primary antibodies against $\mathrm{GABA}_{\mathrm{B} 1(\mathrm{a}, \mathrm{b})} \mathrm{R}(\mathrm{AB} 2256,1: 5000$; Millipore Bioscience Research Reagents) and $\mathrm{GABA}_{\mathrm{B} 2} \mathrm{R}(\mathrm{AB} 5394,1: 5000$; Millipore Bioscience Research Reagents) were tested for specificity in knock-out mice (Schuler et al., 2001; Gassmann et al., 2004), and the $\mathrm{GABA}_{\mathrm{B} 1(\mathrm{a}, \mathrm{b})} \mathrm{R}$ antibody was found to be specific in all regions of the $\mathrm{OB}$. A rabbit primary antibody against mCherry was used to amplify dendrites infected with phosphoglycerate kinase-mCherry lentivirus (1: 4000; Rockland). Secondary antibodies were goat Alexa Fluor-564 and guinea pig Alexa Fluor-647 (Invitrogen).

Confocal imaging. Images (LSM-610; Carl Zeiss) were taken in stacks with a $100 \mathrm{~nm} z$ increment within the first $10 \mu \mathrm{m}$ of a slice. Paired GCs of different ages resided in either the same stack or immediately adjacent regions of the same slice, and identical imaging parameters were used for each pair. Each channel was spectrally isolated with its own filter set, and we found no cross-channel bleed-through in slices lacking one of the three fluorophores.

Colocalization analyses. The profiles of GC apical dendrites were isolated with Imaris (Bitplane), and mean $\mathrm{GABA}_{\mathrm{B} 1} \mathrm{R}$ intensity was quantified within dendrite masks in the same optical plane using custom software written in Python and ImageJ/Fiji. To determine $\mathrm{GABA}_{\mathrm{B} 1} \mathrm{R}$ localization, thresholded dendrite images were eroded using the Gray Morphology plug-in (Prodanov et al., 2006): circular structural element, radius of 200, 400, and $600 \mathrm{~nm}$.

Statistics. All reported variance is \pm SEM. All two-tailed $t$ tests, ANOVA, and regression tests were performed using commercial analysis software (Prism 5.0). Immunofluorescence data were analyzed with a linear mixed model in $\mathrm{R}$ (version 2.15.1) created with nested random variable age (P6 or P60) within neuron pairs (P6 and P60). Multiple comparisons used the R multcomp package (Tukey's all-pair comparison). Identifying optical sections according to neuron added no strength to our model; therefore, stated variance relates to the total number of optical sections in which colocalization was measured $(n=957)$ rather than the number of dendrites $(n=32)$. All box and whisker plots show upper and lower data quartiles around the median, except in Figure 4 in which whiskers on boxes and violins represent the interquartile range $\times 1.5$.

\section{Results}

To control the output of GCs born at specific ages, we birth dated GCs with a lentiviral construct encoding ChR2 (Bardy et al., 2010; Alonso et al., 2012; Fig. 1a) allowing full-field optogenetic stimulation of a cohort of age-matched GCs around a putative postsynaptic MC (Fig. 1b,c). In ChR2 ${ }^{+}$GCs, the number (Fig. 1d,e) and latency (Fig. $1 f$ ) of evoked spikes were controlled by the duration of a flash from an LED array. We observed a tradeoff between spike jitter and both first spike latency and burst length (Fig. 1e). Therefore, to facilitate averaging of synaptic responses across trials, we chose moderate stimulus durations (1-5 ms) to drive GC spiking with minimal jitter.

We characterized the output of GCs with whole-cell recordings from their postsynaptic target, the MC projection neuron, 
and recorded light-evoked IPSCs (Fig. 1g). GABAergic transmission from GCs to MCs occurs across a dendrodendritic synapse in which GABA release can be either spike dependent or asynchronous and tetrodotoxin (TTX) insensitive (Isaacson and Strowbridge, 1998; Fig. 1c). In the presence of glutamatergic blockers (kyurenic acid or NBQX plus APV), we observed that, with increasing LED duration, IPSC latency declined toward a minimum, similar to what we observed with GC spikes (Fig. 1, compare $e, j)$. ChR2-evoked IPSCs were abolished by $\mathrm{GABA}_{\mathrm{A}} \mathrm{R}$ antagonists (Fig. $1 h$ ) as well as by TTX at different stimulus durations (1-5 ms; Fig. 1i), indicating that brief ChR2 stimulation evokes GABA release in a synchronous and TTX-sensitive manner.

We searched for differences in the synaptic physiology of GC populations born at different times using an optogenetic differential screen in which we simultaneously monitored the GABAergic output of a ChR2-stimulated GC population born around the time of injection and an electrically stimulated GC population representing a random sample of birth dates (Fig. $2 a$ ). We discovered that $\mathrm{GABA}_{\mathrm{B}} \mathrm{R}$ agonist $R / S$-baclofen $(100 \mu \mathrm{M})$ had no effect on the first peak of light-evoked IPSCs in GCs born at P60, whereas $\mathrm{GABA}_{\mathrm{B}} \mathrm{R}$ activation depressed the MC IPSC after electrical stimulation (Isaacson and Vitten, 2003; Fig. 2b,c). To avoid potential caveats of ChR2-evoked release, viral injections were made at P60 and P6 to directly compare two GC populations controlled by ChR2. The rate of GC neurogenesis peaks at approximately P6 (Batista-Brito et al., 2008), and we reasoned that this population strongly overlaps with the population of cells targeted by our electrical stimulation. Measuring the amplitude of the first IPSC peak of ChR2-evoked release revealed that baclofen and $\mathrm{GABA}_{\mathrm{B}} \mathrm{R}$ antagonist (CGP 55845, $10 \mu \mathrm{M}$ ) similarly modulated GABA release of P6 infected GCs and electrically stimulated GCs, in contrast to P60 GCs, which were resistant to $\mathrm{GABA}_{\mathrm{B}} \mathrm{R}$ modulation (change in IPSC amplitude from baseline: P60 baclofen, $1.1 \pm 0.1, n=13$; P60 CGP 55845, $1.0 \pm 0.2, n=$ 10; P6 baclofen, $0.5 \pm 0.1, n=12$; P6 CGP 55845, $0.8 \pm 0.1, n=$ 8; electrically stimulated baclofen, $0.5 \pm 0.1, n=11$; electrically stimulated CGP 55845, $0.8 \pm 0.1 n=7$; Fig. $2 c$ ). Importantly, P60 infected GCs remained resistant to baclofen in conditions of increased release probability, indicating that the lack of effect was not attributable to a saturated depression of release (Fig. $2 f$ ).

These data indicate that $\mathrm{GABA}_{\mathrm{B}} \mathrm{R}$ function relates to the age at which a neuron is born. However, $\mathrm{GABA}_{\mathrm{B}} \mathrm{R}$ function could also relate to the age of the neuron or the age of the animal. For neurons infected at P6, we found that the slope of the correlation between the age of the neuron and the efficacy of baclofen was not significantly different from zero $\left(R^{2}=0.205, p>0.1\right)$ but that there was a weak but significant correlation for neurons infected at P60 $\left(R^{2}=0.312, p=0.047\right.$; Fig. $\left.2 d\right)$. In addition, among electrical responses, there was no significance to the correlation between the age of the animal and baclofen sensitivity $\left(R^{2}=\right.$ $0.176, p>0.1$; Fig. $2 e$ ). Together, these data indicate that $\mathrm{GABA}_{\mathrm{B}} \mathrm{R}$ function in early postnatal-born GCs does not change with the age of the neuron or the animal.

In addition to presynaptic depression of release, $\mathrm{GABA}_{\mathrm{B}} \mathrm{Rs}$ can dampen neural activity through a variety of postsynaptic mechanisms, including the activation of potassium channels (Lüscher et al., 1997), and by kinase-mediated modification of $\mathrm{GABA}_{\mathrm{A}}$ Rs (Connelly et al., 2013; Tao et al., 2013). Therefore, we sought to determine whether postsynaptic $G_{A B A} R$ function contributed to our results. We found that the postsynaptic potency of a puff of $\mathrm{GABA}_{\mathrm{A}}$ agonist muscimol $(100 \mu \mathrm{M})$ was unaffected by baclofen administration (Fig. 3a), nor did baclofen
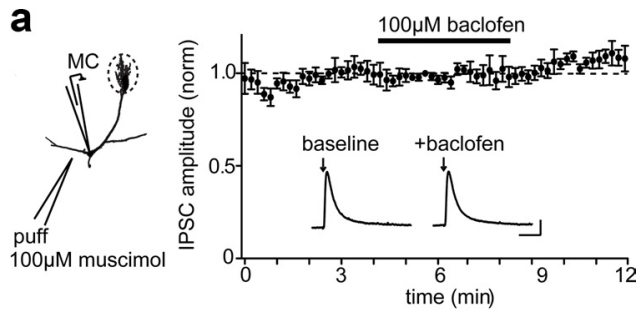

b
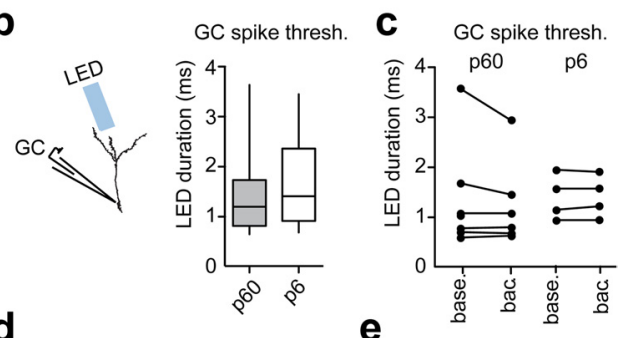

d
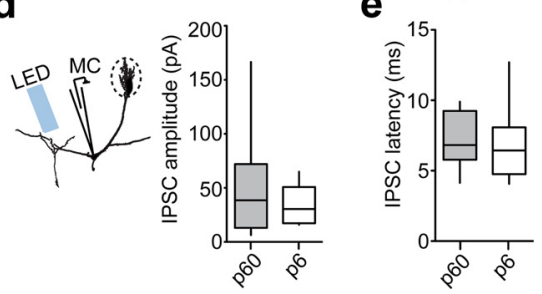

Figure 3. No effect of $G A B A_{B} R$ activation through alternative mechanisms. $\boldsymbol{a}$, Average peak IPSC evoked by brief ( $200 \mathrm{~ms}$ ) puff of GABA agonist muscimol ( $100 \mu \mathrm{m}$ ) before and after 100 $\mu \mathrm{m}$ baclofen administration. Inset, Example muscimol-evoked currents. Calibration: 1s, $50 \mathrm{pA}$. $\boldsymbol{b}$, Average optical threshold to spike measured from loose-patch recordings. c, Threshold to spike before (base.) and after (bac.) $100 \mu \mathrm{m}$ baclofen administration. $\boldsymbol{d}$, Average amplitude of IPSCs evoked by ChR2 from the baseline data of Figure 2c. e, Average onset latency of IPSCS evoked by ChR2 from the baseline data of Figure $2 c$.

change the rate, amplitude, or kinetics of spontaneous IPSCs recorded alongside light and electrically evoked IPSCs (data not shown), indicating that postsynaptic $\mathrm{GABA}_{\mathrm{B}}$ Rs did not modify $\mathrm{GABA}_{\mathrm{A}} \mathrm{Rs}$ in our recording conditions. In addition, we determined whether the excitability of GCs was altered by neuronal age or $\mathrm{GABA}_{\mathrm{B}} \mathrm{R}$ activation and found that $\mathrm{ChR} 2{ }^{+} \mathrm{GCs}$ born at P60 had similar optical threshold to spike as those born at P6 (P60, $1.4 \pm 0.3 \mathrm{~ms}, n=12$; P6, $1.7 \pm 0.4 \mathrm{~ms}, n=6$; $p>0.5$; Fig. $3 b)$, and in neither group was this threshold altered by baclofen $(\mathrm{P} 60, \Delta 0.1 \pm 0.1 \mathrm{~ms}, n=6 ; \mathrm{P} 6, \Delta 0.01 \pm 0.02 \mathrm{~ms}, n=4 ; p>0.3$; Fig. $3 c)$. Finally, the amplitude (P60, $49 \pm 12$ pA; P6, $35 \pm 5$ pA; $p>0.1$; Fig. $3 d$ ) and onset latency (P60, $7.1 \pm 0.5 \mathrm{~ms}, n=13 ; \mathrm{P} 6$, $6.7 \pm 0.7 \mathrm{~ms}, n=12 ; p>0.5$; Fig. $3 e$ ) of baseline IPSCs was not significantly different between GCs infected at P6 and P60, indicating that these two groups of neurons were activated within a similar regimen.

A simple explanation for why adult-born GCs may resist $\mathrm{GABA}_{\mathrm{B}}$ modulation is that they do not express the $\mathrm{GABA}_{\mathrm{B}} \mathrm{R}$ protein. To directly compare $G_{A B A_{B}} R$ expression by GCs of different ages, injections of mCherry and GFP lentiviral vectors were made at P6 and P60 into the same animal (Fig. $4 a-c$ ), resulting in two minimally overlapping populations of labeled GCs $(5.28 \%$ overlap: 106 of 1883 of P6 GCs were reinfected at P60). Quantifying specific immunoreactivity to the $\mathrm{GABA}_{\mathrm{B} 1(\mathrm{a}, \mathrm{b})} \mathrm{R}$ subunit (Schuler et al., 2001; Gassmann et al., 2004; see Materials and Methods) revealed a surprising increase of colocalized signal in the $\mathrm{P} 60$ population ( $\mathrm{P} 60$ mean density, $3800 \pm 800$ SD; $\mathrm{P} 6$ mean density, $3500 \pm 900$ SD; $p<0.02$; Fig. $4 d$ ). In addition, numerically eroding the dendritic mask in each optical section revealed that $\mathrm{P} 60$ neurons also had greater internal $\mathrm{GABA}_{\mathrm{B} 1(\mathrm{a}, \mathrm{b})} \mathrm{R}$ colocal- 
ization than P6 neurons $\left(p<0.001, R^{2}=\right.$ 0.550; Fig. 4e). When dendrite erosion was considered in the statistical model, the difference between P60 and P6 neurons became more significant than by just comparing non-eroded profiles (see Materials and Methods). This is most clearly seen comparing $\mathrm{GABA}_{\mathrm{Bl}(\mathrm{a}, \mathrm{b})} \mathrm{R}$ colocalization in $\mathrm{P} 60$ profiles without erosion to profiles with maximal erosion (no erosion to $600 \mathrm{~nm}, p<0.0001$ ) or between moderately eroded and maximally eroded profiles $(200-600 \mathrm{~nm}, p=0.01)$. These results suggest that the functional resistance of adult-born neurons to $\mathrm{GABA}_{\mathrm{B}} \mathrm{R}$ activation is not attributable to an absence of protein but instead might involve altered localization of the $\mathrm{GABA}_{\mathrm{B} 1(\mathrm{a}, \mathrm{b})} \mathrm{R}$ subunits within adult-born GCs.

\section{Discussion}

The data presented here are consistent with a model in which, in the majority of neurons, $\mathrm{GABA}_{\mathrm{B}} \mathrm{R}$ acts presynaptically at the dendrodendritic synapse to depress release probability (Isaacson and Vitten, 2003), but in adult born neurons redistributed dendritic $\mathrm{GABA}_{\mathrm{B}} \mathrm{R}$ results in a resistance to $G_{A B A} R$ suppression of GABA release. What remains unclear is the nature of the switch that differentiates postnatal-born from adult-born GCs.

One hypothesis is that $\mathrm{GABA}_{\mathrm{B}}$ resistance may be acquired by neurons integrating into an adult circuit. We found that $\mathrm{GABA}_{\mathrm{B}}$ function did not relate to the age of the animal or the age of the neuron. However, it remains possible that resistance to $\mathrm{GABA}_{\mathrm{B}}$ function may be acquired before the age of neurons recorded in this study. Established adult circuits may negate $\mathrm{GABA}_{\mathrm{B}}$ function in immature neurons, perhaps through activity-dependent receptor internalization (Guetg et al., 2010) in a way that is not possible in a developing neural circuit.

An alternative hypothesis is that the neurogenic niche changes after early postnatal neurogenesis to produce functionally distinct subpopulations of interneurons. For instance, some subtypes of $\mathrm{OB}$ interneurons, specifically calretinin ${ }^{+} \mathrm{GCs}$ and the calbindin ${ }^{+}$, parvalumin $^{+}$, and calretinin ${ }^{+}$periglomerular subpopulations, are generated at different rates during early postnatal neurogenesis (Batista-Brito et al., 2008) before establishing a stable proportionality that lasts throughout adulthood (Mobley et al., 2013). In the hippocampus and cerebellum, the relative abundance of $G_{A B A} R$ splice forms changes during early postnatal development (Fritschy et al., 1999; Ritter et al., 2005). Similarly, in the OB, differences in $\mathrm{GABA}_{\mathrm{B}} \mathrm{R}$ subunit expression may have a lasting impact on many interneurons, including adult-born neurons (Panzanelli et al., 2004). It remains to be seen if any element of the $G_{A B A}$ functional pathway shows a similarly time-restricted pattern of expression in GCs.

It was reported recently that GCs are highly active in awake animals and can profoundly shape how MCs code odor informa-
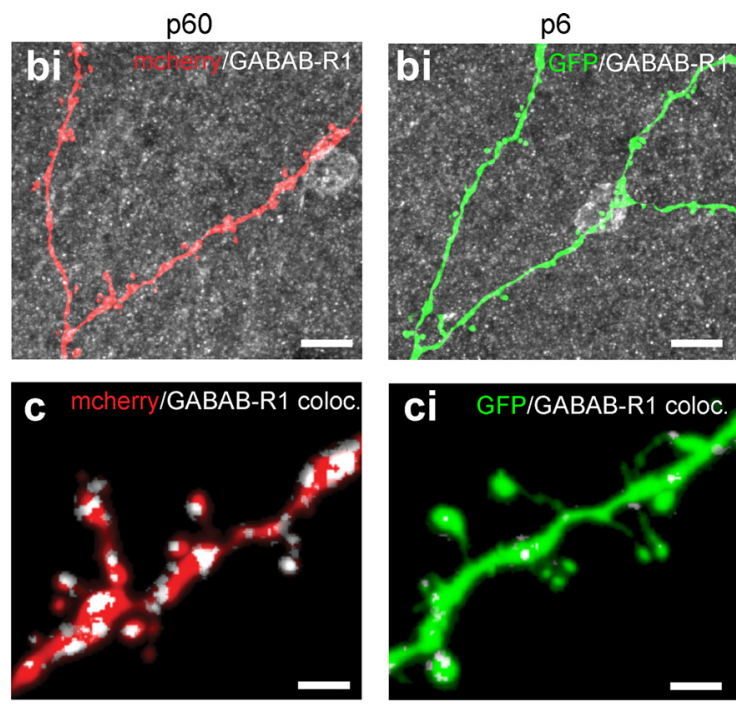

e

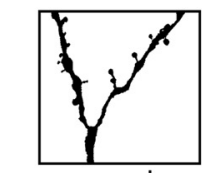

no erosion

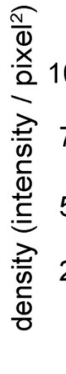

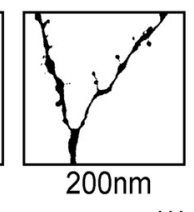
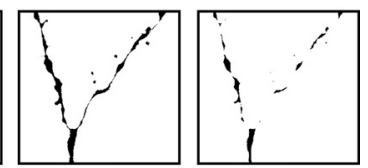

$400 \mathrm{~nm}$

$600 \mathrm{~nm}$
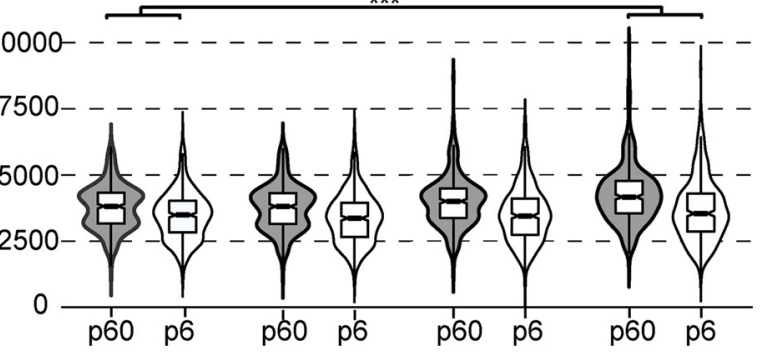

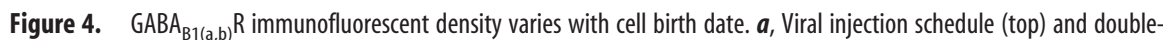

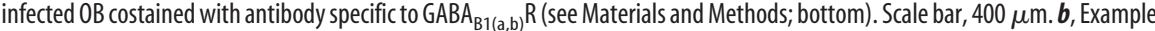
apical dendrites of P60 (red, $\boldsymbol{b}$ ) or P6 (green, $\boldsymbol{b i}$ ). Scale bar, $10 \mu \mathrm{m}$. $\boldsymbol{c}$, Magnification of maximal intensity projection of colocalized ( $\mathrm{R}$ immunoreactivity (white) of P60 (red, c) or P6 (green, ci) GCs. Scale bar, $2 \mu \mathrm{m}$. $\boldsymbol{d}$, Colocalized signal density in dendrite masks (no erosion to $600 \mathrm{~nm}$ erosion; top) created by removing the outermost layer of pixels (pixel, $100 \mu \mathrm{m}^{2}$ ) and violin plots (bottom) showing the density $\left(\Sigma\right.$; pixel intensity/thresholded area) of $\mathrm{GABA}_{\mathrm{B} 1(\mathrm{a}, \mathrm{b})} \mathrm{R}$ immunofluorescence within a mask as a function of erosion and cell birth date. The interaction between cell age and erosion indicates that $G_{A B A_{B 1}(a, b)} R$ is concentrated more in the center of P60 dendrites (no erosion to $600 \mathrm{~nm},{ }^{*} p<0.0001 ; 200-600 \mathrm{~nm}, p=0.01$; see Materials and Methods).

tion (Kato et al., 2012). In the majority of GCs born during postnatal development, the GABA released during periods of high activity may be partially suppressed by $\mathrm{GABA}_{\mathrm{B}} \mathrm{R}$ activation, as has been reported in vitro (Isaacson and Vitten, 2003). In contrast, our results suggest that adult neurogenesis produces a unique subpopulation of GCs that are resistant to $\mathrm{GABA}_{\mathrm{B}} \mathrm{R}$ suppression of GABA release. This would enable spikes from adult-born GCs to have a more reliable GABAergic influence on MCs than those of GCs born earlier during development. Functionally, this may result in increased synchronization of MC ensembles (Lepousez and Lledo, 2013) by their adult-born GABAergic contacts, resulting in adult-born GCs having a unique influence over olfactory behavior.

\section{References}

Alonso M, Lepousez G, Sebastien W, Bardy C, Gabellec MM, Torquet N, Lledo PM (2012) Activation of adult-born neurons facilitates learning and memory. Nat Neurosci 15:897-904. CrossRef Medline

Bardy C, Alonso M, Bouthour W, Lledo PM (2010) How, when, and where 
new inhibitory neurons release neurotransmitters in the adult olfactory bulb. J Neurosci 30:17023-17034. CrossRef Medline

Batista-Brito R, Close J, Machold R, Fishell G (2008) The distinct temporal origins of olfactory bulb interneuron subtypes. J Neurosci 28:3966-3975. CrossRef Medline

Carleton A, Petreanu LT, Lansford R, Alvarez-Buylla A, Lledo PM (2003) Becoming a new neuron in the adult olfactory bulb. Nat Neurosci 6:507518. CrossRef Medline

Connelly WM, Fyson SJ, Errington AC, McCafferty CP, Cope DW, Di Giovanni $G$, Crunelli V (2013) $\mathrm{GABA}_{\mathrm{B}}$ receptors regulate extrasynaptic $\mathrm{GABA}_{\triangle}$ receptors. J Neurosci 33:3780-3785. CrossRef Medline

Fritschy JM, Meskenaite V, Weinmann O, Honer M, Benke D, Mohler H (1999) GABAB-receptor splice variants GBla and GB1b in rat brain: developmental regulation, cellular distribution and extrasynaptic localization. Eur J Neurosci 11:761-768. CrossRef Medline

Gao Y, Strowbridge BW (2009) Long-term plasticity of excitatory inputs to granule cells in the rat olfactory bulb. Nat Neurosci 12:731-733. CrossRef Medline

Gassmann M, Shaban H, Vigot R, Sansig G, Haller C, Barbieri S, Humeau Y, Schuler V, Müller M, Kinzel B, Klebs K, Schmutz M, Froestl W, Heid J, Kelly PH, Gentry C, Jaton AL, Van der Putten H, Mombereau C, Lecourtier L, et al. (2004) Redistribution of $\mathrm{GABA}_{\mathrm{B} 1}$ protein and atypical $\mathrm{GABA}_{\mathrm{B}}$ responses in $\mathrm{GABA}_{\mathrm{B} 2}$-deficient mice. J Neurosci 24:6086-6097. CrossRef Medline

Guetg N, Abdel Aziz S, Holbro N, Turecek R, Rose T, Seddik R, Gassmann M, Moes S, Jenoe P, Oertner TG, Casanova E, Bettler B (2010) NMDA receptor-dependent GABAB receptor internalization via CaMKII phosphorylation of serine 867 in GABAB1. Proc Natl Acad Sci U S A 107: 13924-13929. CrossRef Medline

Isaacson JS, Strowbridge BW (1998) Olfactory reciprocal synapses: dendritic signaling in the CNS. Neuron 20:749-761. CrossRef Medline

Isaacson JS, Vitten $\mathrm{H}$ (2003) $\mathrm{GABA}_{\mathrm{B}}$ receptors inhibit dendrodendritic transmission in the rat olfactory bulb. J Neurosci 23:2032-2039. Medline

Kato HK, Chu MW, Isaacson JS, Komiyama T (2012) Dynamic sensory representations in the olfactory bulb: modulation by wakefulness and experience. Neuron 76:962-975. CrossRef Medline

Kelsch W, Lin CW, Mosley CP, Lois C (2009) A critical period for activitydependent synaptic development during olfactory bulb adult neurogenesis. J Neurosci 29:11852-11858. CrossRef Medline

Lepousez G, Lledo PM (2013) Odor discrimination requires proper olfactory fast oscillations in awake mice. Neuron, in press.
Lin CW, Sim S, Ainsworth A, Okada M, Kelsch W, Lois C (2010) Genetically increased cell-intrinsic excitability enhances neuronal integration into adult brain circuits. Neuron 65:32-39. CrossRef Medline

Lüscher C, Jan LY, Stoffel M, Malenka RC, Nicoll RA (1997) G proteincoupled inwardly rectifying $\mathrm{K}^{+}$channels (GIRKs) mediate postsynaptic but not presynaptic transmitter actions in hippocampal neurons. Neuron 19:687-695. CrossRef Medline

Mobley AS, Bryant AK, Richard MB, Brann JH, Firestein SJ, Greer CA (2013) Age-dependent regional changes in the rostral migratory stream. Neurobiol Aging 34:1873-1881. CrossRef Medline

Nissant A, Bardy C, Katagiri H, Murray K, Lledo PM (2009) Adult neurogenesis promotes synaptic plasticity in the olfactory bulb. Nat Neurosci 12:728-730. CrossRef Medline

Panzanelli P, López-Bendito G, Luján R, Sassoé-Pognetto M (2004) Localization and developmental expression of $\mathrm{GABA}_{\mathrm{B}}$ receptors in the rat olfactory bulb. J Neurocytol 33:87-99. CrossRef Medline

Prodanov D, Heeroma J, Marani E (2006) Automatic morphometry of synaptic boutons of cultured cells using granulometric analysis of digital images. J Neurosci Methods 151:168-177. CrossRef Medline

Ritter B, Ochojski M, Kühn T, Schwarzacher SW, Zhang W (2005) Subcellular vesicular aggregations of GABAB R1a and R1b receptors increase with age in neurons of the developing mouse brain. Cell Tissue Res 319: 181-189. CrossRef Medline

Schuler V, Lüscher C, Blanchet C, Klix N, Sansig G, Klebs K, Schmutz M, Heid J, Gentry C, Urban L, Fox A, Spooren W, Jaton AL, Vigouret J, Pozza M, Kelly PH, Mosbacher J, Froestl W, Käslin E, Korn R, et al. (2001) Epilepsy, hyperalgesia, impaired memory, and loss of pre- and postsynaptic $\mathrm{GABA}_{\mathrm{B}}$ responses in mice lacking $\mathrm{GABA}_{\mathrm{B} 1}$. Neuron 31:47-58. CrossRef Medline

Tao W, Higgs MH, Spain WJ, Ransom CB (2013) Postsynaptic GABA $A_{B}$ receptors enhance extrasynaptic $\mathrm{GABA}_{\mathrm{A}}$ receptor function in dentate gyrus granule cells. J Neurosci 33:3738-3743. CrossRef Medline

Whitman MC, Greer CA (2007) Synaptic integration of adult-generated olfactory bulb granule cells: basal axodendritic centrifugal input precedes apical dendrodendritic local circuits. J Neurosci 27:9951-9961. CrossRef Medline

Yokoyama TK, Mochimaru D, Murata K, Manabe H, Kobayakawa K, Kobayakawa R, Sakano H, Mori K, Yamaguchi M (2011) Elimination of adultborn neurons in the olfactory bulb is promoted during the postprandial period. Neuron 71:883-897. CrossRef Medline 